\title{
LOKALITAS PADA DESAIN RUANG BERSAMA DI KAMPUNG LEDOK, KAWASAN TEMENGGUNGAN KOTA MALANG
}

\author{
Mochammad Najib ${ }^{1}$, Subhan Ramdlani ${ }^{2}$, Damayanti Asikin ${ }^{3}$ \\ ${ }^{1}$ Jurusan Arsitektur Fakultas Teknik Universitas Brawijaya \\ ${ }^{2,3}$ Laboratarium Desain Permukiman dan Kota Jurusan Arsitektur FTUB \\ Jl. Jl. MT Haryono No. 167 Malang \\ *Email: ${ }^{2}$ sramdlaani.premium@gmail.com; ${ }^{3}$ damayantiariestadi@yahoo.co.id
}

\begin{abstract}
ABSTRAK
Fenomena ruang-ruang perkotaan yang hanya dipandang sebagai ruang ekonomi, industry, perdagangan dan jasa, menempatkan ruang-ruang untuk kepentingan publik berada pada ujung prioritas penyediaan ruang. Demikian pula yang terjadi pada permukiman kampung kota, dengan kompleksitas kualitas ruang dan lokalitasnya, seringkali penempatan ruang untuk publik menjadi pilihan terakhir (ruang sisa/negative space) yang tidak terencana dalam ruang permukiman kampung kota (Putri,2012). Di tengah keterbatasan lahan dan keragaman setting fisik, sebenarnya masih bisa ditemukan potensi ruang sosial, budaya, dengan kompleksitas teritori, bentuk dan kemajemukan penggunanya. Ruang bersama (communal space) ini memiliki dinamika dan pola yang menjaga warga untuk saling meningkatkan kualitas daya hidup, ruang komunitas belajar lintas generasi, dengan nilai-nilai kearifan local pada pengelolaannya. Potensi serupa ditemukan di kampong Ledok kawasan Temenggungan di pusat kota Malang, yang sedang berupaya mencari dan membentuk ruang-ruang bersama (communal space) tersebut melalui setting dan atribut ruang, dinamikapola ruang serta teritori ruang Implementasinya dipaparkan melalui dua metode desain, secara programatik dan pragmatik. Secara programatik, artinya membahas program aktifitas dan fungsi serta pola ruang, sedangkan secara pragmatik, membahas tentang penerapan ide dan nilai yang terkandung, yang mengarah pada struktur ruang kawasan. Pengembangan ide desainnya, berawal dari pemetaan pola aktifitas dan waktu berlangsungnya (incidental), kemudian berlanjut pada pemetaan fungsi, pelaku, dan karakteristik lokal. Pemanfaatan ruang, waktu dan batas yang beragam dan fleksibel, memungkinkan digunakan metode superimposed yang menghasilkan multilayer program dalam satu komponen ruang. Dengan pemahaman aktifitas sosial dan budaya lokal masyarakat setempat, termasuk melibatkan potensi material lokal mereka, ruang bersama yang terjadi sangat kuat unsur lokalitasnya.
\end{abstract}

Kata Kunci: ruang bersama, fleksibiltas, lokalitas.

\section{PENDAHULUAN}

Masyarakat kampung kota adalah masyarakat yang mengalami proses urbanisasi dan mulai tergerus arus globalisasi dengan semakin meninggalkan ciri masyarakat desa. Masyarakat desa identik dengan masyarakat agraris yang lebih menggantungkan pada sistem mata pencaharian bercocok tanam baik persawahan maupun perkebunan. Kehidupannya juga didasarkan pada ikatan kekeluargaan yang erat. Masyarakat Desa awalnya merupakan suatu "gemeinschaft" yang memiliki unsur gotong royong yang kuat. Karakter masyarakat desa merupakan face to face group, mereka saling mengenal seolah-olah mengenal dirinya sendiri (Bintarto, 1989). Fenomena yang terjadi dalam kehidupan sosial-budaya masyarakat kampung saat ini adalah corak kehidupan masyarakat yang berupa nilai-nilai kebersamaan dan kegotongroyongan semakin menipis. Perubahan ini akan berpengaruh juga terhadap perubahan ruang-ruangnya, salah satunya adalah ruang bersama.

Di balik perubahan tersebut, keterbatasan lahan dan lingkungan fisik kampung-kampung kota ternyata masih memiliki eksistensi ruangruang sosial budayanya. Ruang bersama, merupakan ruang dimana sesama warga meningkatkan kualitas daya hidup, ruang komunitas belajar lintas generasi. Ruang bersama merupakan jenis ruang yang selalu ada 
pada masyarakat Nusantara (Pangarsa, 2006). Ruang bersama memiliki fungsi penting, karena merupakan wadah untuk aktivitas sosial bersama yang didasari keguyuban dan kebersamaan. Ruang bersama pada masa kini bukan merupakan ruang yang bersifat tetap, ruang bersama memiliki sifat kesementaraan dan kesejenakan. Kesementaraan dan kesejenakan itulah dalam rangkaian perjalanan menjadikan fungsi tempat itu ikut mengalami kesementaraan. Ruang bersama yang hadir terbentuk karena adanya unsur komponen ruang atau setting dan atribut ruang yang sesuai. Ruang bersama dalam keterbatasan dan setting lingkungan yang ada selalu mengalami sebuah dinamika kompleksitas dan kemajemukan subjek-pelaku ruangnya.

Ruang bersama masih terdengar asing karena sebutan "Ruang Publik" lebih banyak dikenal di permukaan pendidikan. Di Nusantara telah dikenal ruang-ruang bersama seperti Tenean di Madura, atau natar di Flores, atau natah di Bali, di masa kekinian gang kampung adalah jalan sekaligus ruang bersama (Prijotomo dan Pangarsa,2010).

Ruang bersama atau communal space merupakan ruang untuk berbagi bersama yang biasanya digunakan sebagai interaksi antara anggota suatu komunal, dimana dapat menimbulkan kebersamaan atau keguyuban. Terbentuknya lingkungan permukiman dimungkinkan karena adanya proses pembentukan hunian sebagai wadah fungsional yang dilandasi oleh pola aktivitas manusia serta pengaruh setting atau rona lingkungan, baik yang bersifat fisik maupun non fisik (sosialbudaya) yang secara langsung mempengaruhi pola kegiatan dan aktivitas dalam ruang (Rapoport, 1990).

Berbeda dengan ruang publik, ruang bersama memiliki kualitas teritorialnya, bukan berarti claim atau menguasai suatu tempat, melainkan sebagai pengelola ruangnya. Hal ini sudah seharusnya sebagai perhatian khusus, salah satunya arsitektur untuk melestarikan sikap kearifan lokal masyarakat dalam mengelolanya. Teritorialitas tak ubahnya terkandung nilai kearifan lokal dalam pemanfaatanya tentang keselarasan hubungan antar manusia dengan lingkungannya. Sehingga hal ini perlu dijaga-pelihara dengan menumbuhkembangkan potensi tersebut. Porteous (1977) menyatakan teritorialitas adalah sebagai batas dimana organisme hidup menentukan teritori dan mempertahankannya, terutama dari kemungkinan intervensi atau agresi pihak lain.

Konsep ini pada awalnya dikembangkan untuk organisme hidup bukan manusia. Altman (1980) memaparkan bahwa teritorialitas merupakan hubungan individu atau kelompok dengan setting fisiknya, yang dicirikan oleh rasa memiliki, dan upaya pengelolaan terhadap pemanfaatan. Pengertian pengelolaan (kontrol) oleh Altman (1975) diartikan dengan mekanisme mengatur batas antara orang yang satu dengan lainnya melalui penandaan atau personalisasi untuk menyatakan bahwa tempat tersebut ada yang memilikinya.

Personalisasi menurut Altman (1975) adalah pernyataan kepemilikan individu, atau kelompok terhadap suatu tempat, melalui tandatanda inisial diri. Pernyataan kepemilikan tersebut bisa secara konkrit (wujud fisik) atau simbolik (non fisik). Secara konkrit menurut Altman (1980) ditandai dengan adanya penempatan (occupancy), dan secara simbolik dengan keterikatan tempat (place attachment). Uraian-uraian di atas memberikan pengertian yang lebih terinci lagi mengenai teritorialitas, yaitu upaya-upaya individu atau kelompok dalam melakukan kontrol atau pengelolaan terhadap ruang.

\section{METODE KAJIAN-PERANCANGAN}

Pada tahap pengamatan merupakan upaya menelaah secara kuantitatif dan kualitatif dengan menggunakan pendekatan fenomenologi yakni melakukan pengamatan terhadap proses dan bentuk perwujudan ruang bersama yang berkaitan dengan setting dan atribut, dinamika dan pola serta teritorialitas ruang (pemaknaan hubungan antar manusia dengan pemanfaatan ruangnya) sehingga didapatkan sebuah kesimpulan karakteristik ruang bersama Kampung Ledok Temenggungan. Karakter tersebut diolah-lanjut pada tahap memunculkan ide pengembangan ruang bersama (desain) sehingga kajian ini berdiri pada alur proses paradigmatik-pragmatik.

Lokasi studi ruang bersama ini, terletak pada kawasan Kampung Ledok Temenggungan Kecamatan Ksatrian Malang. Lokasi ini merupakan salah satu perkampungan padat yang berada di Kota Malang. Kampung ini berada di daerah cekungan (ledokan) berbatasan dengan 
Jl Basuki Rahmat dan rel kereta api. Batas-batas fisik kawasan adalah pada bagian Utara berbatasan dengan Jalan Trunojoyo, pada bagian Selatan berbatasan dengan pemukiman penduduk, pada bagian Barat berbatasan dengan Jalan Gatot Subroto dan pada bagian Timur berbatasan dengan lereng rel kereta api (Gambar $1)$.

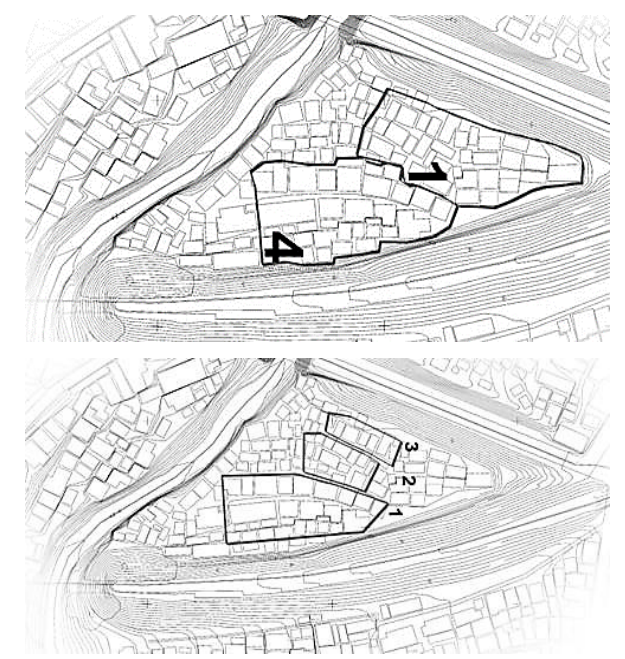

Gambar 1. Lokasi Studi

Area studi tepatnya berada pada kawasan RT01 dan RT04, RW12 yang merupakan bagian muka kawasan kampung. Pada tahap pengamatan, dipilih tiga cluster yang cukup mewakili di lapangan. Pada lokasi Kampung Temenggungan Ledok, kurang lebih terdapat 205 rumah. Jumlah rumah yang dijadikan sampel dalam penelitian ini adalah 30 rumah, yang terdapat pada tiga kluster permukiman.

\section{HASIL DAN PEMBAHASAN}

Lokasi pengamatan yang sebatas pada RT02 dan RT04 RW12 Kelurahan Ksatrian, Malang. Sehingga lokasi pengamatan terbagi atas 3 area lokasi. Pada pengamatan awal dilakukan pemetaan potensi ruang bersama yaitu dengan mengambil titik objek pada lokasi pengamatan. Titik pengamatan berada pada hubungan gang dan teras (emper) dikarenakan pada pengamatan awal lokasi tersebut kerap hadirnya ruang bersama. Tipologi yang memiliki potensi hadirnya ruang bersama, yaitu area Dalem, Teras, Gang, Lapangan, Warung, Jedhing/Sumur dan Musholah.

1. Kondisi Lingkungan

a. Lokasi 1

Kondisi lingkungan pada lokasi pertama cenderung memiliki kontur yang datar dengan gang cukup lebar antara 2-3m, tidak memiliki vegetasi peneduh hanya berupa sedikit pot-pot vegetasi di sisi pinggir gang. Orientasi arah-hadap rumah saling bertemu fasad dengan beberapa ada pertemuan fasad depan dengan bagian samping rumah. Pada lokasi ini terdapat sebuah lapangan yang menjadi simpul gang. Dengan ketidakberadaan unsur pernaungan pada vegetasi dan minim unsur pernaungan maka ruang bersama kerap hadir pada waktu sore hari dan malam hari. Keberadaan kontur dan jalur sirkulasi yang cukup lebar menjadikannya sebuah potensi kehadiran ruang yang melibatkan pelaku lebih majemuk. Fasilitas umum yang terdapat pada lokasi area 1 yaitu berupa lapangan dan warung (Gambar 2).

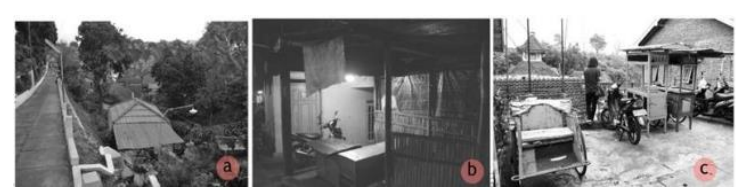

Gambar 2. Kondisi Lokasi 1

\section{b. Lokasi 2}

Pada area lokasi pengamatan kedua terdapat perbedaan ketinggian kontur tanah. Keadaan topografi yang berkontur relatif menurun sehingga banyak kasus terjadi perbedaan level antar tetangga terkecuali pada RT01 bagian utara masih memiliki perbedaan kontur yang relatif sedikit. Selain keadaan topografi, keadaan sirkulasi kampung lebih bersifat organik dan sempit dikarenakan gang berada disela-sela bangunan dengan lebar 1$2 \mathrm{~m}$ (Gambar 3).

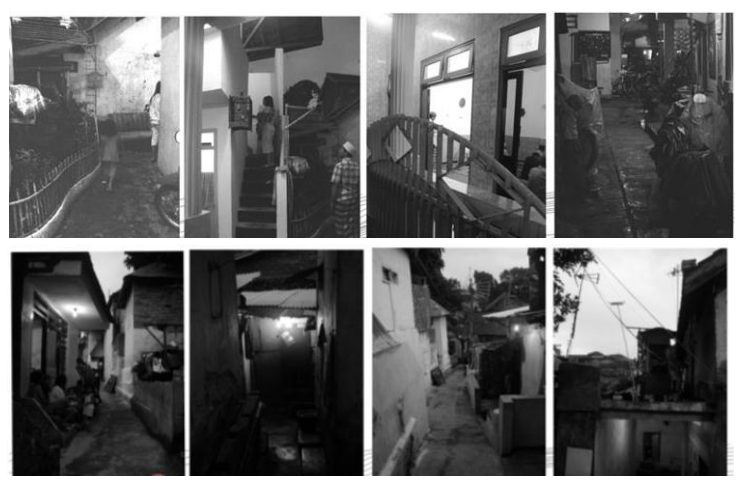

Gambar 3. Kondisi Lokasi 2 dan 3

c. Lokasi 3

Tidak memiliki perbedaan yang signifikan terhadap lokasi kedua, pada lokasi pengamatan ketiga terdapat banyak kontur yang lebih curam, sehingga gang kampong sangat jarang sekali hadir ruang bersama, 
terkecuali pada fasilitas umum, yaitu ruang cuci dan fasilitas gang sebagai area jemur dan penempatan barang kerja pribadi. Keadaan gang seolah berupa teras rumah dikarenakan jarang rumah pada lokasi ketiga yang memiliki teras. Selain keadaan topografi, keadaan sirkulasi kampung lebih bersifat organik dan sempit dikarenakan gang berada disela-sela bangunan dengan lebar $11,5 \mathrm{~m}$.

Berdasarkan pengamatan kondisi lingkungan (pernaungan, kontur, tata massa,

Tabel 1. Kondisi Lingkungan Tiap Lokasi Pengamatan aksesibilitas, jangkauan, fasilitas ruang dan jumlah ruang) didapatkan bahwa lokasi 1 lebih memiliki banyak kelapangan sehingga memiliki kebebasan secara batasan fisik.

Sedangkan lokasi 2 dan 3 memiliki pernaungan cukup banyak, sehingga bayang dan gelap memiliki intensitas yang tinggi. Namun aksesibilitas dan fasilitas umum di keduanya cukup kecil/sedang (Tabel 1).

\begin{tabular}{|c|c|c|c|c|c|c|c|}
\hline \multirow[t]{2}{*}{ TEMPAT } & \multirow[b]{2}{*}{ Pernaungan } & \multicolumn{2}{|c|}{ KONDISI LINGKUNGAN } & \multirow[b]{2}{*}{ Aksesibilitas } & \multirow[b]{2}{*}{ Jangkauan } & \multirow[b]{2}{*}{$\begin{array}{l}\text { Fasilitas } \\
\text { ruang }\end{array}$} & \multirow[b]{2}{*}{$\begin{array}{l}\text { Jumlah } \\
\text { Ruang }\end{array}$} \\
\hline & & Kontur & Tata massa & & & & \\
\hline AREA 1 & $\begin{array}{l}\text { Sedikit, } \\
\text { Terang }\end{array}$ & Datar & $\begin{array}{l}\text { Linier } \\
\text { Berkelompok }\end{array}$ & mudah & Luas & $\begin{array}{l}\text { Lapangan, } \\
\text { Warung, }\end{array}$ & Banyak \\
\hline AREA 2 & Sedang & Sedang & $\begin{array}{l}\text { Linier dan } \\
\text { Berkelompok }\end{array}$ & $\begin{array}{l}\text { Relatif } \\
\text { mudah }\end{array}$ & Sedang & $\begin{array}{l}\text { ledhing, } \\
\text { Warung, } \\
\text { Mushola, }\end{array}$ & Sedang \\
\hline AREA 3 & $\begin{array}{l}\text { Banyak, } \\
\text { Gelap }\end{array}$ & Banyak & $\begin{array}{l}\text { Cluster/ } \\
\text { berkelompok }\end{array}$ & Relatif sulit & Kecil & $\begin{array}{l}\text { Sumur, } \\
\text { tandon }\end{array}$ & Sedikit \\
\hline
\end{tabular}

(Sumber: Hasil analisis, 2014)

2. Setting dan Atribut Ruang

Ruang bersama pada umumnya merupakan ruang publik yang pada saat tertentu menjadi ruang bersama, dengan memenuhi setting dan atribut ruang tertentu. Namun, lingkungan rumah juga menjadi ruang bersama dalam lingkungan permukiman. Hasil pengamatan didapatkan bahwa ruang bersama yang terbentuk di Kampung Ledok Temenggungan memiliki setting atau latar ruang antara lain adanya kemudahan akses (aksesibilitas), adanya fasilitas umum yang dipakai bersama, adanya naungan atau teduhan yang berupa vegetasi atau bayangbayang massa bangunan, adanya kelapangan tempat, adanya kebebasan secara visual, adanya kenyamanan, dan adanya kebebasan secara batasan fisik atau tidak ada penyekat (Tabel 2).

Tabel 2. Setting dan Atribut Ruang

\begin{tabular}{|c|c|c|c|c|c|c|c|c|c|}
\hline \multirow{2}{*}{ TEMPAT } & \multicolumn{7}{|c|}{ Setting } & \multicolumn{2}{|c|}{ Atribut } \\
\hline & $A C S$ & $F S$ & $S H$ & $S P C$ & $V S$ & $\mathrm{CMF}$ & PHSC & Keseharian & Insidental \\
\hline Teras & Ya & - & $\mathrm{Ya}$ & Ya & Ya & $\mathrm{Ya}$ & Ya & Naungan & $\begin{array}{l}\text { Tempat duduk, } \\
\text { karpet, tikar, janur, } \\
\text { dekorasi }\end{array}$ \\
\hline Gang & $\mathrm{Ya}$ & Ya & Ya & Ya & Ya & - & Ya & $\begin{array}{l}\text { Naungan, pot vegetasi, } \\
\text { tempat duduk, alat jemur, } \\
\text { kendaraan parkir }\end{array}$ & $\begin{array}{l}\text { Tempat duduk, tenda, } \\
\text { janur, dekorasi, sound } \\
\text { system }\end{array}$ \\
\hline Lapangan & $\mathrm{Ya}$ & $\mathrm{Ya}$ & $\mathrm{Ya}$ & Ya & $\mathrm{Ya}$ & - & Ya & $\begin{array}{l}\text { Vegetasi, alat jemur, } \\
\text { kendaraan parkir }\end{array}$ & $\begin{array}{l}\text { Tempat duduk, tenda, } \\
\text { janur, dekorasi, sound } \\
\text { system }\end{array}$ \\
\hline Dalem & Ya & - & $\mathrm{Ya}$ & - & - & $\mathrm{Ya}$ & - & $\begin{array}{l}\text { Tempat duduk, sajian untuk } \\
\text { tamu, tikar }\end{array}$ & $\begin{array}{l}\text { Tempat duduk, } \\
\text { karpet, tikar, tenda, } \\
\text { janur, dekorasi }\end{array}$ \\
\hline Warung & Ya & Ya & Ya & - & Ya & $\mathrm{Ya}$ & - & Barang dagangan, naungan & -- \\
\hline Musolah & Ya & Ya & Ya & - & $\cdot$ & Ya & $\cdot$ & $\begin{array}{l}\text { Kitab suci, peralatan } \\
\text { ibadah, karpet }\end{array}$ & Dekorasi \\
\hline Jeding & Ya & Ya & Ya & - & - & - & - & $\begin{array}{l}\text { Peralatan cuci, sumur, alat } \\
\text { jemur }\end{array}$ & -- \\
\hline \multicolumn{10}{|c|}{ 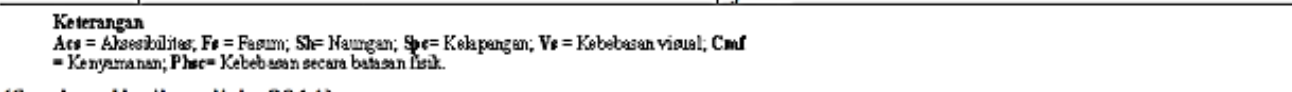 } \\
\hline \multicolumn{10}{|c|}{ (Sumber: Hasil analisis, 2014) } \\
\hline
\end{tabular}


3. Aktivitas dan Pelaku Ruang

Aktivitas yang banyak menggunakan ruang bersama meliputi aktivitas sehari-hari rutin, aktivitas rutin mingguan, bulanan, tahunan, dan aktivitas pada waktu khusus (insidental). Pada aktivitas sehari-hari, kebersamaan terjadi karena adanya faktor kebutuhan, kesamaan aktivitas, dan adanya latar ruang yang memungkinkan aktivitas tersebut terjadi. Aktivitas bersama sehari-hari terjadi pada saat mengambil air, beribadah, bermain, beristirahat setelah bekerja (cangkruk), parkir, aktivitas jual beli, mengasuh anak, dan menjemur. Pola aktivitas bersama harian biasanya cenderung terjadi atas latar belakang kedekatan dan faktor kesamaan aktivitas. Sedangkan aktivitas bersama rutin mingguan, bulanan dan tahunan biasanya terkait dengan kegiatan keagamaan, perayaan atau ritual misalnya pengajian mingguan, arisan bulanan, Musyawarah Warga, Sholat Hari Raya, dan acara pernikahan.

Dari hasil pengamatan pada aktivitas rutin harian yang dilakukan pada tempat yang menjadi ruang bersama, antara lain area dalem, teras, sumur (jedhing), langgar (musholah), lapangan, warung dan jalan (gang), terjadi dinamika dalam pemanfaatannya. Dinamika tersebut terletak pada fungsi, pelaku, dan sifat ruang. Dinamika dalam penggunaan ruang tersebut juga terjadi pada aktivitas rutin dan pada aktivitas khusus (insidental) (Tabel 3).

Tabel 3. Aktifitas dan Pelaku Ruang Bersama

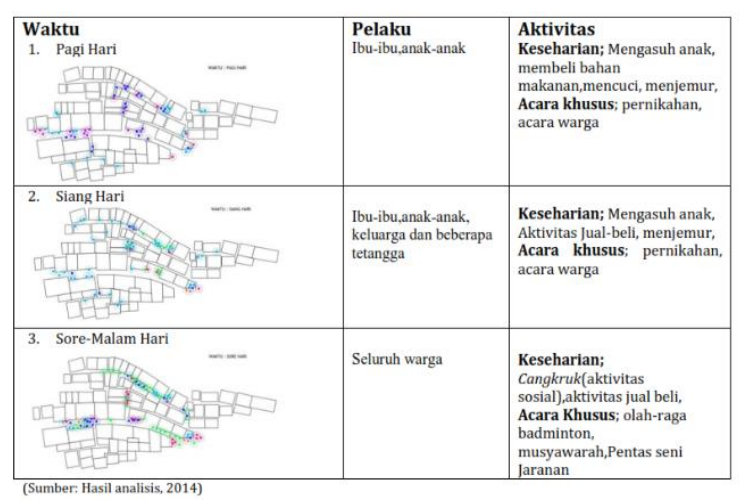

\section{Pola Ruang}

Setelah mendapatkan dinamika ruang yang terjadi dan hubungannya terhadap setting lokasi hadirnya ruang maka dapat ditarik kesimpulan bahwa ruang bersama Kampung Temenggungan Ledok Malang memiliki kategorisasi jenis Ruang berdasarkan intensitas, kompleksitas dan durasi kehadiran ruang tersebut.

a. Ruang Bersama Mikro

Ruang bersama skala mikro merupakan ruang yang memiliki kemajemukan paling sedikit dengan intensitas yang tinggi, dikarenakan unsur pelaku ruang ruang bersama hanya beberapa keluarga ataupun 1 keluarga dengan aktivitas keseharian. Tempat yang dimanfaatkan adalah berupa pelataran yang dikarenakan tidak sedikit warganya tidak memilik ruang tamu, sehingga pelatan (atau teras) dan gang lah sebagai area perluasan pemanfaatan ruang, aktivitas dilakukan kebanyakan hanya dilakukan pada sore hari atau malam hari.

b. Ruang Bersama Messo

Ruang bersama kategori Messo merupakan ruang bersama dalam skala antar-kelompok warga, satu atau antar RT. Skala waktu dalam pemanfaatan ruang yaitu harian, mingguan dan bulanan. Tempat yang sering dimanfaatkan sebagai ruang bersama antara lain Gang, teras, warung. Aktivitasnya banyak hal, mulai dari cangkrukan, Rapat dan Arisan RT yang berlangsung rutin bulanan.

c. Ruang Bersama Makro

Aktivitas bersama rutin mingguan, bulanan dan tahunan cenderung memanfaatkan ruang Kampung Temenggungan Makro. Sehingga skala pemetaannya meliputi seluruh bagian kampung. Aktivitas bersama rutin yang diselenggarakan mingguan yaitu pengajian untuk perempuan, laki-laki dan anak-anak. Tempatnya bergiliran antar peserta. Aktivitas bulanan, antara lain Posyandu. Kegiatan Posyandu letaknya di Rumah Belajar, kecuali jika ada kegiatan khusus, akan di selenggarakan di kantor desa (diluar kampung). Kegiatan tahunan, berkaitan dengan hari raya agama Islam. Ruang bersama yang terjadi adalah di area Masjid, ruang bersama saat bersilaturrakhmi, yaitu jalan, pelataran, teras (emper), dan ruang bersama saat penyembelihan hewan qurban bertempat di lapangan bulu tangkis yang terletak di gang utama. 
Aktivitas bersama yang terjadi pada waktu khusus terkait dengan perayaan, misalnya pernikahan, sunatan, kelahiran, kematian, atau syukuran. Penyelenggara acara tersebut bisa merupakan salah satu keluarga ataupun beberapa warga. Pemanfaatan ruangnya gang kampung, pada pelataran, gang atau bantaran sungai, dengan ditambahnya tenda sebagai naungan fisik.

5. Teritorialitas Ruang Bersama

Pada analisis sistem keruangan yaitu tentang pengelolaan ruang-ruang yang ternaungi di dalam, luar ataupun transisi diantaranya. untuk mendapatkan sistem tersebut maka perlu adanya analisis karakteristik unsur pembentuk teritori dan perubahan fungsi publik-privat di ruang dalam, ruang luar ataupun ruang didalamnya pada eksisting yang nantinya akan dapat diolah lanjutkan dalam sistem keruangan yang baru. Ruang memiliki batas atau teritorial, walaupun batas tersebut bukan merupakan batas fisik ataupun topografi, melainkan pada pengelolaan ataupun pengolahannya (Tabel 4).

Kuncinya ada pada notion ruang bersama sebagai teritori. Bukan dalam arti menguasai,

\begin{tabular}{|l|l|l|l|}
\hline & Bentuk & Komponen & Pembatas \\
\hline & $\begin{array}{l}\text { Teritori ruang bersama pada aktivitas } \\
\text { pentas jaranan melingkupi area teras } \\
\text { (emper) rumah milik warga dengan } \\
\text { perluasan menggunakan gang dan teras } \\
\text { tetangga hadapan rumah. Teras dengan } \\
\text { ukuran 3x4m berbentuk persegi dan } \\
\text { gang dengan lebar 3m berbentuk paduan } \\
\text { antara ramp dan tangga. } \\
\text { Ruang ini berada pada skala mezzo }\end{array}$ & $\begin{array}{l}\text { Komponen berupa } \\
\text { komponen ruang yaitu } \\
\text { berupa perabot dan } \\
\text { vegetasi pada kondisi } \\
\text { eksisting sebagai berikut: } \\
\text { motor parkir, cahaya } \\
\text { lampu, perabot duduk }\end{array}$ & $\begin{array}{l}\text { Teritori dibatasi dengan } \text { fix } \text { berupa pagar setinggi Im pada teras, } \\
\text { kontur ramp dan tangga, pernaungan } \\
\text { perluasan teras dan simpangan gang. } \\
\text { Semi-fixed element pada motor yang } \\
\text { diparkir dan perabot tetangga di gang } \\
\text { Non-fixed element berupa penerangan } \\
\text { lampu dan batas imajiner berupa cucuran } \\
\text { air hujan. }\end{array}$ \\
\hline $\begin{array}{l}\text { Pada saat tidak adanya aktivitas pentas } \\
\text { jaranan ruang berubah menjadi skala } \\
\text { mikro. Teritori ruang hanya melingkupi } \\
\text { area teras rumah }\end{array}$ & $\begin{array}{l}\text { Komponen berupa } \\
\text { lampu,pernaungan,warung } \\
\text { bakso,motor parkir }\end{array}$ & $\begin{array}{l}\text { Pembatas teritori pun hanya pada pagar } \\
\text { pembatas setinggi 1 m, pernaungan } \\
\text { (bayang-bayang) dan material lantai teras }\end{array}$ \\
\hline
\end{tabular}

b. Pembentukan teritori berdasarkan fungsi publik-privat

Teritori Ruang Pentas Jaranan

Pentas latihan jaranan dilaksanakan di salah satu teras rumah warga yang bukan merupakan anggota dari salah satu kelompok seni jaranan. Dalam perspektif model fungsi publik-privat keruangan teras yang bersifat semipublik berubah menjadi publik begitupun terjadi pada teras tetangga depan. Sebagaimana yang telah tetapi dalam arti ada pihak yang bertanggung-jawab. Karakter ruang yang meliputi bentuk, ukuran, pembatas, dan komponen ruang sangat berkaitan satu sama lain (Hermanto, 2008). Perubahan bentuk akan mempengaruhi ukuran ruang yang ada. Perubahan bentuk ruang juga dapat diamati dengan adanya batas-batas (teritori) yang membentuk ruang tersebut, baik batas fix element, semi fix element, maupun batas ruang dengan non fix element. Aktivitas yang dipilih memiliki kemajemukan dan keragaman pelaku dalam kehadiran ruang bersamanya.

a. Pembentukan Teritori berdasarkan perubahan bentuk, ukuran, pembatas, dan komponen ruang

Karakter ruang yang meliputi bentuk, ukuran, pembatas dan komponen ruang sangat berkaitan satu antara yang lain. Perubahan bentuk akan mengikuti ukuran yang ada. Perubahan bentuk juga dapat diamati dengan adanya batas-batas yang membentuk ruang tersebut, baik batas fix element, semi fixed element, maupun batas ruang yang non-fixed element. 
berubah menjadi publik berdasarkan
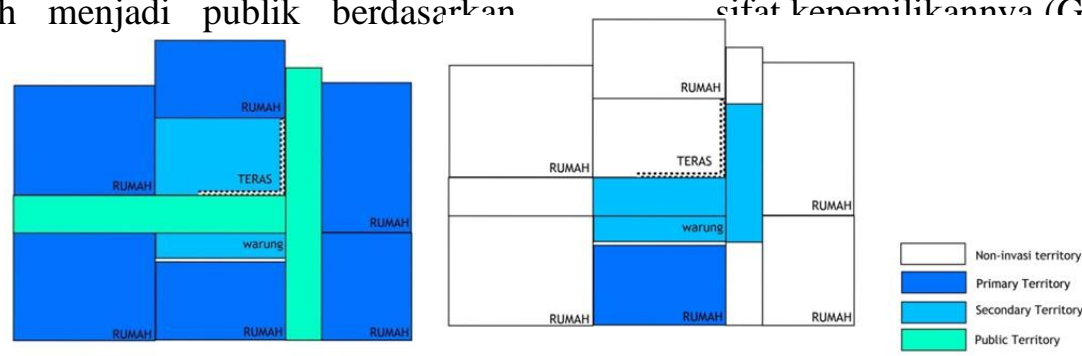

Gambar 4. Perluasan Teritori Publik-Privat Pentas Jaranan

Teritori Ruang Musyawarah RT

Musyawarah RT dilaksanakan di

Rumah Pak RT yang mengalami

perluasan ke depan dan ke samping dengan batas teritori yang semakin bersifat organik dan fleksibel mendekati relatif (Tabel 5).

Tabel 5. Pembentukan Teritori Musyawarah RT

\begin{tabular}{|l|l|l|l|}
\hline & Bentuk & Komponen & Pembatas \\
\hline 1 & $\begin{array}{l}\text { Teritori ruang pada musyawarah } \\
\text { adalah ruang keluarga rumah pak } \\
\text { RT yang meluas hingga teras dan } \\
\text { teras tetangga samping kanan dan } \\
\text { kiri dan gang. }\end{array}$ & $\begin{array}{l}\text { Komponen berupa: karpet,tikar, } \\
\text { piring-piring makanan, sound- } \\
\text { system, lampu,sofa dan tempat } \\
\text { duduk }\end{array}$ & $\begin{array}{l}\text { Teritori dibatasi dengan fix element } \\
\text { perbedaan level bangunan pada } \\
\text { tetangga depan. } \\
\text { Semi-fixed element pada motor yang } \\
\text { diparkir dan perabot tempat duduk } \\
\text { diletakkan di jalan } \\
\text { Non-fixed element berupa lampu } \\
\text { penerangan dan suara speaker. }\end{array}$ \\
\hline 2 & $\begin{array}{l}\text { Pada saat tidak adanya aktivitas } \\
\text { musyawarah. Teritori ruang hanya } \\
\text { melingkupi area teras rumah } \\
\text { sebagai salah satu ruang bersama } \\
\text { mikro. }\end{array}$ & $\begin{array}{l}\text { Komponen meja \& bangku warung, } \\
\text { motor parkir, pot tanaman }\end{array}$ & $\begin{array}{l}\text { Pembatas teritori: ketinggian lantai } \\
\text { teras yang merupakan fixed element. } \\
\text { Material dan jendela, dinding dan } \\
\text { pintu rumah }\end{array}$ \\
\hline
\end{tabular}

Dalam perspektif model fungsi publikprivat keruangan secara mikro yaitu rumah yang dimanfaatkan sebagai ruang bersama mengalami perubahan teritori, yang berawal pada ruang tamu dan bagian dalam rumah bersifat privat mengalami perubahan menjadi bersifat publik. Teras yang bersifat semi-publik berubah menjadi publik, begitupun terjadi pada teras tetangga depan. Sebagaimana yang telah diungkapkan sebelumnya, bahwa fungsi publik privat berkaitan erat dengan peletakan komponen ruang didalamnya. Posisi rumah yang bersebelahan samping kanan dan kiri dengan perbedaan level teras setinggi $10 \mathrm{~cm}$ menyebabkan perubahan komponen terjadi di kedua rumah. Salah satunya adalah keberadaan karpet mulai menginvasi teritori dan berubah sifat kepemilikan pada perabot yang sebelumnya sudah ada di teras tersebut (Gambar 5).
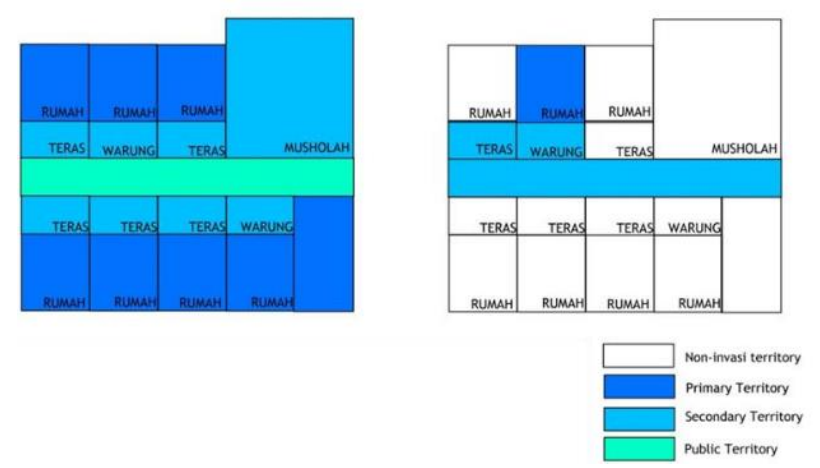

Gambar 5. Perluasan Teritori Publik-Privat Musyawarah RT

6. Analisis Programatik 
Aktivitas terbagi atas aktivitas rutinitas harian dan aktivitas insidental. Pada aktivitas rutinitas harian adalah berupa aktivitas menjemur, engasuh anak, aktivitas jual beli, aktivitas sosial (cangkruk), parkir bermain dan ronda, sedangkan pada aktivitas insidental yang mencakupi aktivitas acara pernikahan, olahraga bersama, acara ceremonial warga kampung, kerja bakti, aktivitas keagamaan, musyawarah RT, pentas seni jaranan dan acara menonton bersama. Pada aktivitas tersebut menunjukan perlunya analisis sebuah program kebutuhan akan komponen pembentuk ruang. Unsur komponen tersebut pada pembahasan ini adalah kebutuhan akan program ruang yaitu menaungi sebuah fungsi akan aktivitas bersama masyarakat kampung pada ruang bersama. Unsur komponen terkait akan fungsi sedangkan fungsi terkait akan kebutuhan aktivitas, keterkaitan tersebut sama halnya dengan apa yang telah dibahas pada pembahasan dinamika dan pola ruang bersama (Tabel 6).

Tabel 6. Program Aktivitas

\begin{tabular}{|l|l|}
\hline Komponen Program Harian & Komponen Program Insidental \\
\hline $\begin{array}{l}\text { Menjemur } \\
\text { Mengasuh anak } \\
\text { Aktifitas Jual Beli } \\
\text { Parkit } \\
\text { Cangkikuk } \\
\text { Bemain } \\
\text { Ronda }\end{array}$ & \\
\hline
\end{tabular}

Terkait pada perancangan pengembangan secara kawasan maka program tersebut dijadikan sebuah input pada area potensi kawasan. Potensi telah didapat sebelumnya yang merupakan potensi pengembangan ruang bersama berdasarkan hasil pengamatan setting dan dinamika-pola ruang bersama. Arah gerak pengembangan ruang memiliki 4 simpul, diantaranya simpul tersebut yang memiliki potensi ruang bersama yang lebih kompleks dan di antara simpul tersebut cenderung merupakan jenis ruang mikro yang dapat dikembangkan secara makro, karena pemanfaatanya secara bersama lebih dari satu kelompok keluarga. Dari hasil pengamatan sebelumnya maka didapatkan area potensi ruang. Pemetaan dari kelima aktivitas harian adalah tahap lanjut untuk mengetahui alur programatik terkait lokasi ruang. Dari hasil pemetaan ini dilakukan sebuah langkah yang disebut superposisimultilayer program, yaitu langkah memetakan lokasi aktivitas yang terjadi sehingga dapat digabungkan hasil dari pemetaan tersebut dan mendapatkan output berupa sebuah struktur ruang yang akan terbentuk (Gambar 6).
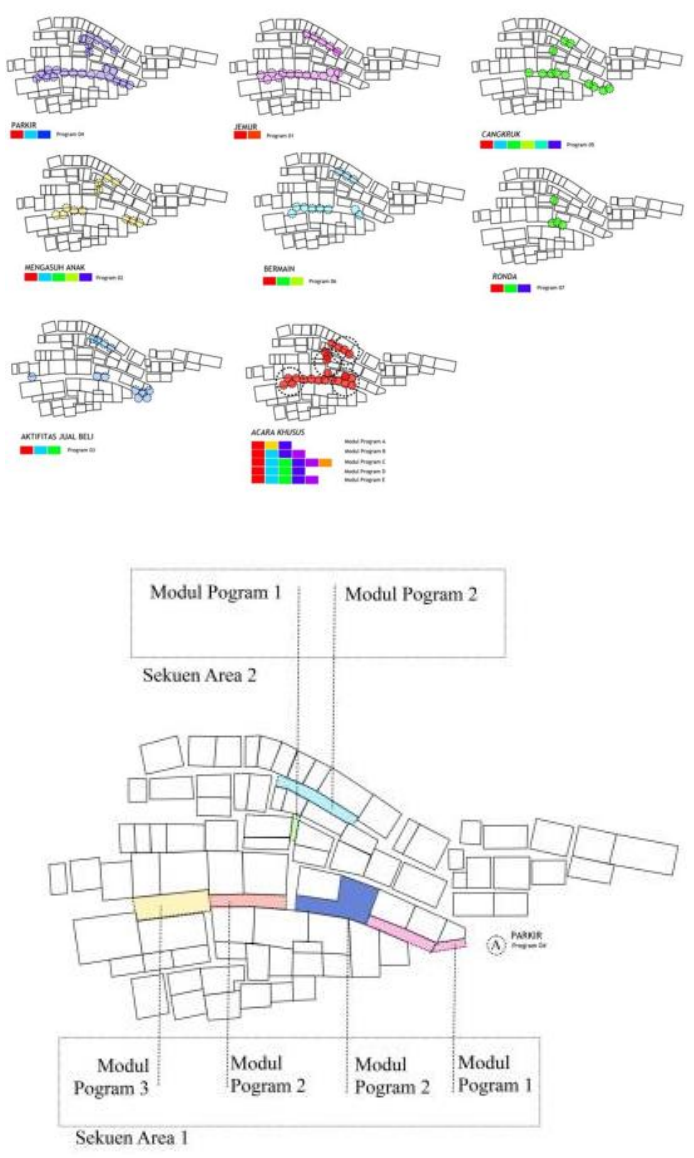
Gambar 6. Pemetaan Aktivitas pada Ruang Bersama Keseharian

Berdasarkan hasil pemetaan selanjutnya memasukkan program yang telah ditentukan sehingga didapatkan multi-program pada setiap titik area lokasi. Untuk mempermudah analisis area tersebut terbagi atas 6 area lokasi pemetaan program. Area ini ditentukan berdasarkan 3 simpul ruang-ruang bersama pada aktivitas insidental didalamnya (ruang makro). Ketiga area tersebut, setiap area memiliki karakter aktivitas didalamnya, hal ini berkaitan dengan keadaan dinamika aktivitasnya dan pemanfaatannya. Ketiga sekuen area tersebut ditentukan 2 kategori berbeda sehingga terdapat 6 area peletakan program tersebut berdasarkan pemetaan aktivitas.

Pembentukan area pun berdasarkan radius aktivitas pada satu titik dan kemampuan ruang tersebut untuk mewadahi aktivitas tertentu. Pada setiap 6 area memiliki kebutuhan komponen kebutuhan sebagai pembentuk ruang.

7. Analisis Diagramatik

Pada pembahasan bentuk merupakan upaya membahasakan kembali hasil dari analisis aspek programatik ruang kedalam bentuk sistem konvertilitas, yaitu bersifat fleksibel secara technical, dapat dibongkar-pasang atau dapat didaya-guna-manfaatkan sebagai fungsi baru. Material yang dipergunakan adalah material lokal setempat baik skala kampung ataupun di luar kampung atau skala kota. Material utama yang digunakan adalah bambu.

Hal yang membedakan antara ruang bersama keseharian adalah intensitas pemanfaatannya. Pada pembahasan programatik dan bentuk ruang telah ditentukan mengenai fungsi dan juga elemen komponen ruang, sehingga selanjutnya adalah memadu-padankan dengan potensi material yang digunakan, material utama yang berupa bambu dan elemen tersier lainnya seperti spanduk sebagai pernaungan, pallet sebagai elemen pendukung, dan botol plastik sebagai elemen dekoratif-interaktif pada media dinding (Gambar 7).

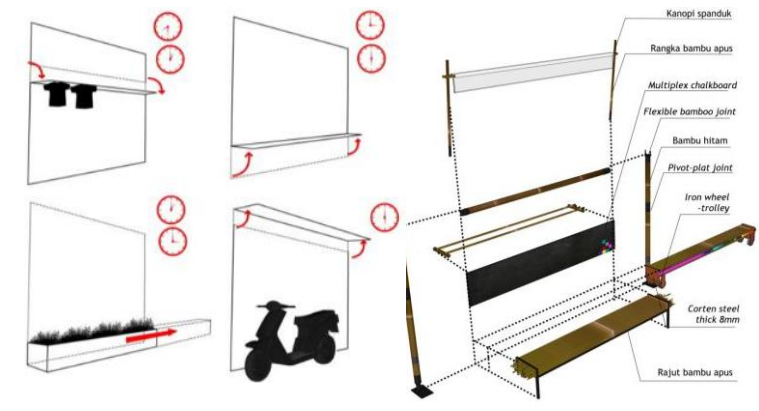

Gambar 7. Analisis Bentuk Komponen RuangDinding

8. Konsep Desain

Secara keseluruhan modul program yang telah ditentukan memiliki kesamaan elemen komponen ruang hanya saja mengalami penambahan sesuai dengan kebutuhan. Secara diagramatik-programatik yang dipadukan dengan daya-kemampuan material sehingga didapatkan alur (skematik) konvertibilitas komponen. Elemen pernaungan dan instalasi jemur memiliki alur konvertibilitas dalam satu waktu, pada saat elemen jemur dibutuhkan maka instalasi jemur akan mengangkat dikarenakan dipergunakan mini katrol untuk memfungsikan diantara dua komponen tersebut (Gambar 8-11).

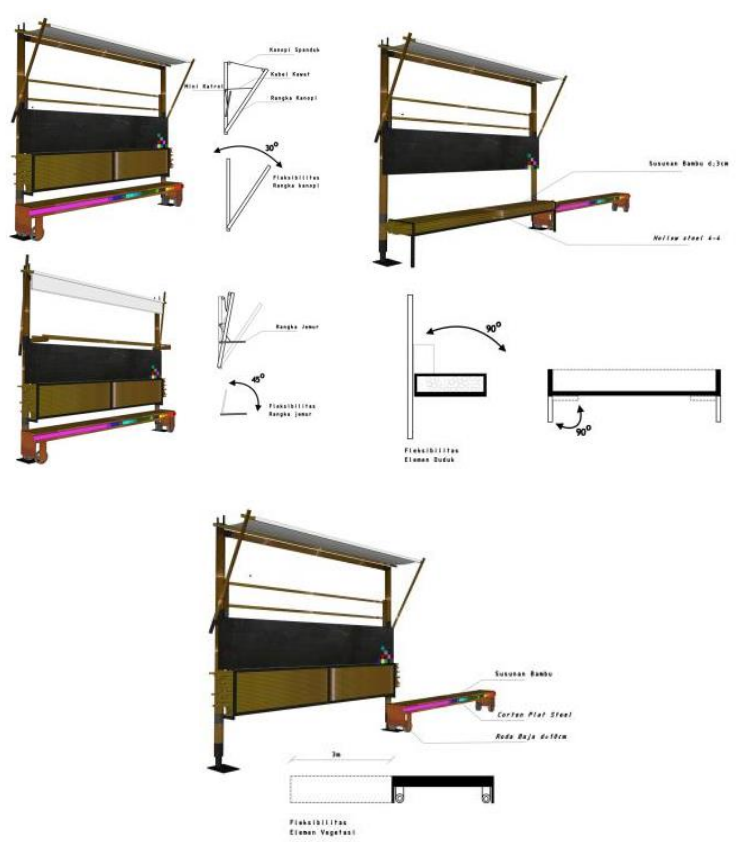

Gambar 8. Komponen Ruang Konvertibilitas 


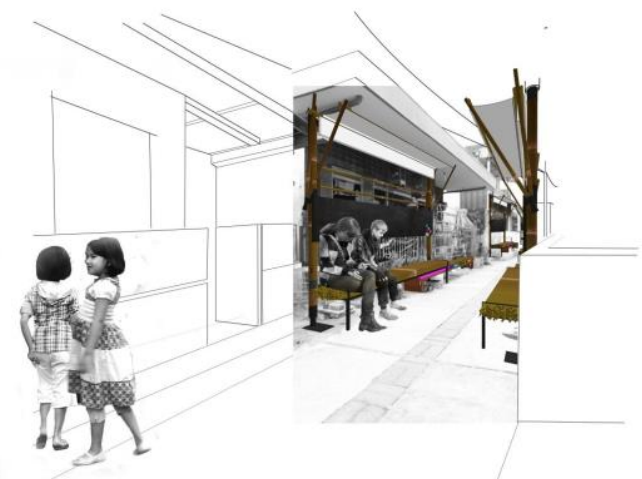

Gambar 9. Konsep Ruang Bersama Keseharian

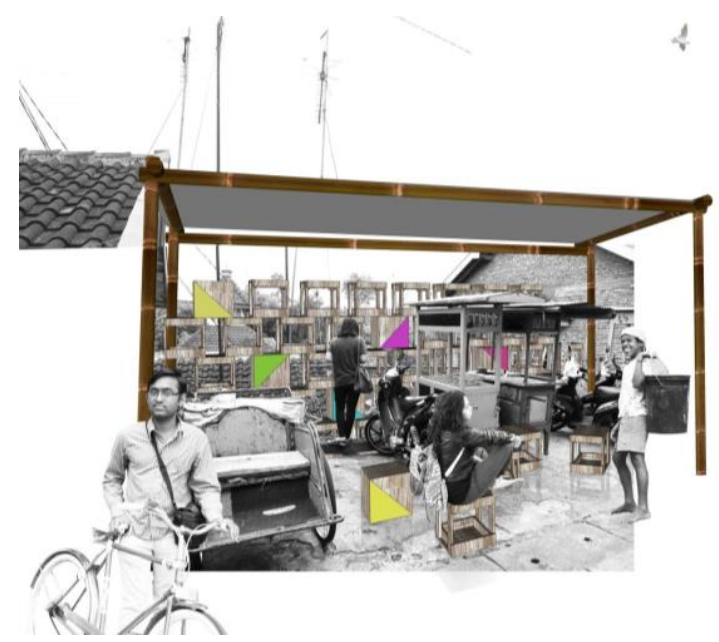

Gambar 10. Konsep Material Pallet

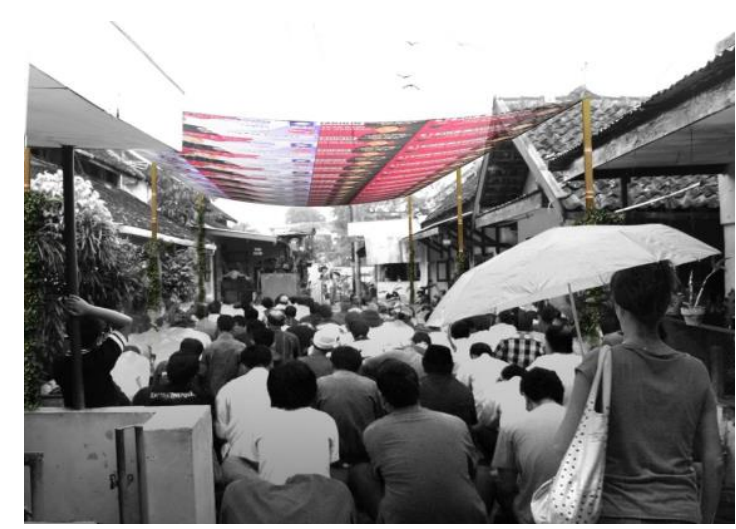

Gambar 11. Konsep Pernaungan pada Ruang Bersama Aktifitas Insidental

\section{KESIMPULAN}

Di tengah keterbatasan lahan dan lingkungan fisik kampung ledok, ternyata masih eksis ruang-ruang sosial-budayanya, yaitu ruang bersama, ruang dimana sesama warga meningkatkan kualitas daya hidup, ruang komunitas belajar lintas generasi.

Berbeda dengan ruang publik, ruang bersama memiliki kualitas teritorialnya, bukan konteks claim atau menguasai suatu tempat, melainkan sebagai batas pengelola ruangnya.

Ruang bersifat dinamis, maka ruang bersama memiliki dinamika dan membentuk sebuah pola. Dengan keterbatasan segala lingkungan fisik pemukiman kampung kota yang padat, tentunya intensitas dinamikanya memiliki kompleksitas ruang dan kemajemukan pelakunya.

Fleksibilitas pengaturan aras teritori terkait domain antar ruang dalam, ruang luar dan ruang transisi diantaranya adalah merupakan teritorialitas yang langka ditemukan di kota.

Dengan sifat dinamika, pola serta teritorialitas maka pengembangan ide desain yang diperuntukkan untuk Ruang Bersama Kampung Ledok Temenggungan Malang pun mengikuti akan karakter ruangnya. Desain yang dibuat memiliki sifat konvertibilitas. Komponen ruang dapat dibongkar-pasang, tata-susun kembali atau memiliki nilai fleksibilitas dalam pemanfaatannya karena beracuan pada sifat ruang yang dinamis.

Konsep struktur dan elemen tiap komponen ruang bersama berisikan tentang nilai kolektifitas, mengingat bahwa ruang bersama milik bersama, yang mewadahi kemajemukan masyarakat dengan material lokal dan berkaitan dengan aspek bangunan yang beradaptasi terkait waktu. Kemajemukan tersebut merupakan sebuah komunitas kekriyaan dengan muatan kegotong-royongan, dan kebersamaan.

\section{Daftar Pustaka}

Altman, I. (1975) The Environment and Social Behavior. Monterey, CA: Wadsworth 1980. HumanBehavior and Enviroment. Plenary Press, NY and London.

Bintarto, R. (1989) Interaksi Desa-Kota dan Permasalahannya. Jakarta: Ghalia Indonesia.

Hermanto, H. (2008) Faktor-faktor yang Berpengaruh Terhadap Perubahan 
Fungsi Ruang di Serambi Pasar Induk Wonosobo. Semarang: Universitas Diponegoro.

Prijotomo, Josef, Pangarsa, Galih Widjil (2010) Rong: Wacana Ruang Arsitektur

Jawa. Ebook Engine.

(www.ruangarsitektur.com, diakses 12 Juli 2013)

Pangarsa, Galih Widjil (2006) Merah Putih Arsitektur Nusantara. [ISBN 979-763628-3]. Yogyakarta: Andi Offset.

Putri, Rr. (2012) Pendekatan teritori pada fleksibilitas ruang dalam tradisi sinoman dan biyada di dusun karang ampel malang, Dimensi (Journal of Architecture and Built Environment), Vol. 39, No. 2, December 2012, 65-76 [ISSN 0126219X]

Porteous, John D. (1977) Environment \& Behavior: Planning and Everyday Urban Life. Michigan: AddisonWaesley.

Rapoport, Amos (1990) The Meaning of the Built Environment: A Nonverbal Communication Approach. 1st Ed., ISBN: 10: 0816511764, pp: 253. Arizona: University of Arizona Press.

Laurens, J.M. (2004) Arsitektur dan Perilaku Manusia. Penerbit PT.

Grasindo,Jakarta. 